\title{
Assessment of the Effects of Newly Fabricated CaO, CuO, ZnO Nanoparticles on Callus Formation Maintainance of Alfalfa (Medicago Sativa L.) Under In Vitro Salt Stress
}

\section{Merve Simsek}

Erzurum Technical University

\section{Busra Yazicilar}

Erzurum Technical University

\section{Fatma Boke}

Erzurum Technical University

Hayrunisa Nadaroglu

Ataturk University: Ataturk Universitesi

Azize Alayli

Sakarya Üniversitesi

ismail Bezirganoglu ( $\square$ ismail.bezirganoglu@erzurum.edu.tr)

Erzurum Technical University https://orcid.org/0000-0003-4079-5998

\section{Research Article}

Keywords: Callus, alfalfa, nanoparticle, confocal laser scanning analysis, in vitro assay

Posted Date: April 5th, 2021

DOl: https://doi.org/10.21203/rs.3.rs-314355/v1

License: (c) (1) This work is licensed under a Creative Commons Attribution 4.0 International License.

Read Full License 


\section{Abstract}

Nanoparticules plays an important role in plant adaptation to abiotic stress, especially in response to salt stress. In this study, two alfalfa lines (Erzurum, and Muş) were used as the material for the response $\mathrm{NaCl}$ to $\mathrm{CuO}, \mathrm{ZnO}$ and $\mathrm{CaO}$ nanoparticules (NPs). $\mathrm{CaO}$ is evident to be higher effective than $\mathrm{CuO}, \mathrm{ZnO}$ in callus induction from leaf explants. The antioxidant enzyme activities were also determined in the callus cultures. The maximum activity in MDA analysis was observed from callus treated of $50 \mathrm{mM} \mathrm{NaCl}$ with $0.8 \mathrm{ppm}$ CuO NPs. The callus induction stage without salt treatments indicated a best result in $0.8 \mathrm{ppm}$ $\mathrm{CaO}$ NPs for $\mathrm{H}_{2} \mathrm{O}_{2}$ value compared to the other NPs. The callus induction stage without salt treatments indicated a best result in $0.8 \mathrm{ppm} \mathrm{CaO} \mathrm{NPs} \mathrm{for} \mathrm{POD} \mathrm{value} \mathrm{compared} \mathrm{to} \mathrm{the} \mathrm{other} \mathrm{NPs} \mathrm{for} \mathrm{POD} \mathrm{activity.}$ The best response in protein rate was obtained from callus induction stage and callus formation stage after $50 \mathrm{mM}$ treatment $\mathrm{NaCl}$ with $0.8 \mathrm{ppm} \mathrm{CuO}$. LSCM analysis evident that the NPs could migitate the negative effects of $\mathrm{NaCl}$ stress by the elimination of stress severity in callus cells. SEM analysis was supported the results obtained by LSCM analysis. Our findings suggest that $\mathrm{CuO}, \mathrm{CaO}$ and ZnO NPs can offer a simple and effective method to protect alfalfa callus from $\mathrm{NaCl}$ stress severity.

\section{Key Message}

Engineered $\mathrm{CaO}, \mathrm{CuO}$ and $\mathrm{ZnO}$ confer a protective response to salt stress in alfalfa callus maintainance. This response verifies with laser scanning confocal analysis and SEM analysis.

\section{Introduction}

Agricultural productivity is significantly constrained by biotic and abiotic environmental factors (Ji et al. 2013). Salt stress is a growing issue which is becoming a serious environmental stress around the world (Jalili et al. 2009; Zhu et al. 2016; Jalili et al. 2019). Salt-induced damage in product yield presumably exceeds damages from all other reasons, since both the severity and periods of the stress are crucial. Excess concentrations of various types of salts such as carbonates, calcium, chlorides, sulfates, magnesium, potassium and sodium, define various salinity growth mediums. Various control strategies have been supposed to challenge salt stress (Yazıcılar et al. 2021; Gao et al. 2016). Salt stress decreases root growth, stem expansion, leaf length, disrupts water-use capacity, and lowers plant water activity. Plants exhibit a difference of metabolic and physiological reactions at cellular and wholeorganism levels against salt stress, thus making it a confusing event (Bezirganoglu 2017). The salt resistance trait is regulated by many physiological defensive strategies through complex enzymatic controlling pathways (Parida et al. 2005; Parihar et al. 2015). Metabolic process affects growth by challenging plants with photosynthesis, protein synthesis and lipid metabolisms. Physiological strategies like osmotic, ionic, oxidative stress and hormonal imbalances are affected due to salt stress. Salinity influences growth cope with of plants by the excess of $\mathrm{Na} \otimes$ and $\mathrm{Cl} \otimes$ ions in the medium that reduces the osmotic potential and inhibits the nutrients and water uptake (Gao et al. 2016). It is important to understand how salt stress challenges signals on the various levels of cells to activate the adaptive process in the plant (Manchanda and Garg 2008). Nanotechnology plays an important role in research 
tools that solutions to the multiple agriculture-related matters. Nanotechnology has a larger application than biotechnology containing gene transformation, genomics, proteomics and bioinformatics and other technologies (Vijayakumar et al. 2010; Kim et al. 2017). Nanotechnologies can provide to enhance product capacity in less yield crops which is contributing in sustainable agriculture.

Moreover, nanotechnology has helped new potential for enhancing the structure of foods, flavour, higher protein content, and improved nutritional values. Nanoparticles have assisted to develop crop productivity by introducing such qualities as biotic resistance and increased abiotic stress resistance to the crops. $\mathrm{CuO}$ and $\mathrm{ZnO}$ oxide nanoparticles protect the plants against stress factors, through improving the activity of cytosolic enzymes (Alabdallah and Alzahrani 2020). Many studies have reported that various nanoparticles have both favourable and unfavourable effects on exogenous application of nanoparticle for the plant development processes, which are concentration-dependent and related to application strategy and targeted plant species (Kim et al. 2017; Ruttkay-Nedecky et al. 2017; Wang et al. 2016).

However, the physiological and molecular responses of callus cells to NPs are still unclear. In vitro cell cultures provide promising technology for the rapid production and stress-tolerant cultivars improved in short period of time (Bezirganoglu et al. 2017; Elmaghrabi and Ochatt 2006). The use of NP can influence the plant metabolism for enhancing the plant development and the capacity of ROS scavenging. The green derived nanoparticles from plants are economical and eco-friendly (Iqbal et al. 2020; Gohari et al. 2020). Callus culture is the suitable resources for rapid production of shoot quality and bio active phytochemicals. Callus can be stimulated further for the in vitro proporagation of whole plants and used to deliver NPs into plants. The treatments of NPs in callus culture increased their content of bioactive molecules in response to biotic and abiotic stress factors (Yazıcılar et al. 2021; Bezirganoglu 2017). The improvement of novel strategy to characterize and clarify NPs in cells and tissues would support a better understanding of the potential effects during in vitro culture of plant tissues. To date, microscopy techniques have been used to study the assimilation and accumulation of NPs in plants under in vitro conditions. Alfalfa is used livestock feed and is superior to other forage crops in terms of nutritional quality. It has a rich and long history and is one of the earliest crops domesticated by human (Putnam et al. 2001). Alfalfa is cultivated for its rich source of proteins, carbohydrates, vitamins, minerals and diatery fibres. It also cultivated for its high yield and nutritional feeding quality, as well as its role on $\mathrm{N}$ fixation, soil conservation (Sakiroglu and Brummer 2017). However, alfalfa production is severely reduction by salt stress. Plants thrive by maintaining cell division and proliferation. Copper is an important micronutrient with many functions including redox reactions and participating the synthesis of chlorophyll and metabolism of carbohydrate and protein. Tolerance of diseases and crop yields can be influenced by deficiency of $\mathrm{Cu}$ (Dimpka et al. 2012) Zn is essential micronutrient participating directly in metabolic activities in plants such as formation of protein and carbonhydrate and synthesis of chlorophly as well as involving in the synthesis of auxin and indole acetic acid IAA from tryptophan. It was found that $\mathrm{Zn}$ key functions in regulation of redoxs systems and conservation of plant cells in response to oxidative stress. Zn deficiency plants have decreased crop productivity and reduced quality of crops (Lian et al. 2019). Understanding the response of alfalfa plants toward salinity stress at the nanobased level and developing salt-resistant cultivars are the vital mandates for its effective management. Till date, no 
previous research article is available in literature to show the effects of, $\mathrm{CuO}$ and $\mathrm{ZnO}$ NPs on callus biomass formation and production of antioxidants in callus cultures of alfalfa. Therefore, the over all objective of the current study was to evaluate the possible effects of NPs on callus induction, biomass formation and extension of desirable levels of resistance to salt stress in alfalfa. Moreover, free radical scavenging activity and the antioxidant enzyme activities were also determined in the callus cultures.

\section{Materials And Methods}

\section{Plant materialandCallus induction}

In our study, two alfalfa lines (Erzurum, and Muş) were used as the material for the response to $\mathrm{CaO}$, $\mathrm{CuO}$ and $\mathrm{ZnO}$ NPs nanoparticulate. The mature seeds were sterilized with $1 \% \mathrm{NaOCl}$ for $5 \mathrm{~min}$, washed several times with sterile distilled water and rinsed with several changes of sterile distilled water overnight at $4^{0} \mathrm{C}$. The mature seeds were cultivated in Petri dishes containing full MS medium (Murashige and Skoog 1962) for 30 days at $25 \pm 1$ and in 16 hours light / 8 hours dark photoperiod at 1500 lux illumination intensity. Leaves were removed aseptically using forceps and placed on MS medium (Murashige and Skoog 1962) with $2 \mathrm{mg} \mathrm{L}^{-1}$ glycine, $4 \mathrm{mg} \mathrm{L}^{-1}$ 2,4-D, $100 \mathrm{mg} \mathrm{L}^{-1}$ myo-inositol, $0.5 \mathrm{mg} \mathrm{L}^{-1}$ nicotinic acid, 0,5 $\mathrm{mg} \mathrm{L}^{-1}$ pyridoxine $\mathrm{HCl}, 0.1 \mathrm{mg} \mathrm{L}^{-1}$ of thiamine $\mathrm{HCl}$ vitamins, $1.95 \mathrm{~g}$ of MES, $50 \mathrm{mg} \mathrm{L}^{-1}$ of ascorbic acid, 20 $\mathrm{g}$ of sucrose, solidified with $7 \mathrm{~g}$ of agar and the $\mathrm{pH}$ adjusted to 5.8 before autoclaving. In sterilization of the vitamins and hormones, $0,22 \mu \mathrm{m}$ of porous cellulose nitrate filters were used and added $0.8 \mathrm{ppm} \mathrm{CaO}$, $\mathrm{CuO}$ and $\mathrm{ZnO}$ NPs. The leaves were incubated in total darkness at $25 \pm 1^{\circ} \mathrm{C}$ temperature for one month.

\section{Green synthesis and structural characterization of $\mathrm{CaO}, \mathrm{CuO}$ and $\mathrm{ZnO}$ NPs}

\section{Preparation of Plant Extract}

The walnut shells to be used in the green synthesizing of $\mathrm{CaO}, \mathrm{CuO}$ and $\mathrm{ZnO}$ NPs NPs were collected from the walnut gardens in Erzurum in August-September 2020 and kept in the refrigerator at $+4{ }^{\circ} \mathrm{C}$ until they were studied.

25 grams of walnut shells were first washed with distilled water, then the walnut shells were broken. The solid particles were then separated from the solution by filtration using filter paper (Watman 1). CaO, CuO and $\mathrm{ZnO} \mathrm{NPs}$ were synthesized using obtained walnut shell extract $0,1 \mathrm{M} \mathrm{Ca}\left(\mathrm{NO}_{3}\right)_{2}, \mathrm{Zn}\left(\mathrm{NO}_{3}\right)_{2}$ and $\mathrm{Cu}\left(\mathrm{NO}_{3}\right)_{2}$ solutions.

\section{Green Synthesis of CaO, CuO and ZnO NPs Nanoparticles}

The synthesis of $\mathrm{CuO}, \mathrm{CaO}$ and $\mathrm{ZnO}$ NPs was synthesized by using the walnut shell extract as reducing agent, using the green synthesis method previously used by Nadaroglu et al 2017.

\section{Characterization of $\mathrm{CaO}, \mathrm{CuO}$ and $\mathrm{ZnO} \mathrm{NPs}$}


The $\mathrm{CaO}, \mathrm{CuO}$ and $\mathrm{ZnO}$ NPs characterization obtained was carried out within the Eastern Anatolia High Technology Application and Research Center (DAYTAM) affiliated to Atatürk University. Scanning Electron Microscopy (SEM) and XRD analysis were used for the characterization of $\mathrm{CaO}$, CuO and ZnO NPs NPs. Information about the size and morphological properties of nanoparticles synthesized in this way was obtained.

\section{Salt stress treatment}

Erzurum and Muş leaf explants were used for callus formation in MS (Murashige and Skoog 1962) medium containing $4 \mathrm{mg} \mathrm{L}^{-1}$ 2,4-D (2,4-dichlorophenoxyacetic acid) and $0.125 \mathrm{mg}$ kinetin including 0.8 ppm $\mathrm{CaO}, \mathrm{CuO}$ and $\mathrm{ZnO}$ NPs nanoparticulate. The total culture duration was one month. Then, callus was obtained from $50 \mathrm{mM}$ salt stress, such as one week and two week medium in terms of salt stress treating callus exposure times. Callus was transferred to hormone MS medium (Murashige and Skoog 1962) 1.0 $\mathrm{mg} / \mathrm{l}$ 2,4-D 2,4-dichlorophenoxyacetic acid) and $1 \mathrm{mg} / \mathrm{l}$ kinetin in the presence of $50 \mathrm{mM} \mathrm{NaCl}$ including $0.8 \mathrm{ppm} \mathrm{CaO}, \mathrm{CuO}$ and $\mathrm{ZnO}$ NPs.

\section{MDA (Malondialdehyde)}

Malondialdehyde was measured using the method of (Heath and Packer 1968) using liquid nitrogen. 0.4 grams of ground callus material was dispersed in $0.5 \%(\mathrm{w} / \mathrm{v})$ thiobarbituric acid solution containing $20 \%$ $(\mathrm{w} / \mathrm{v})$ tricholoroacetic acid. The sample was boiled at $98 \circ \mathrm{C}$ for $30 \mathrm{~min}$. and then quickly taken into an ice bath. The sample content was centrifuged at $3000 \times g$ for $10 \mathrm{~min}$. and the value of the supernatant was monitored at 532 and 600 nm (Heath and Packer 1968; Jaleel et al. 2007; Erdal 2012).

\section{$\mathrm{H}_{2} \mathrm{O}_{2}$ (Hydrogen peroxide)}

$\mathrm{H}_{2} \mathrm{O}_{2}$ (Hydrogen peroxide) content was measured using the method of Sergiev et al. (1997). $0.4 \mathrm{~g}$ of callus material was homogenized in $4 \mathrm{ml}$ of trichloroacetic acid and centrifuged at $4{ }^{\circ} \mathrm{C}$ for $15 \mathrm{~min}$. at $13000 \mathrm{rpm} .2 \mathrm{ml}$ of extract was mixed with $0.8 \mathrm{ml}$ of $\mathrm{KH}_{2} \mathrm{PO}_{4}$ and $1.6 \mathrm{ml}$ of $\mathrm{Kl}$ in test tubes. The absorbance of the callus sample product was measured at $390 \mathrm{~nm}$ using a standard curve with $\mathrm{H}_{2} \mathrm{O}_{2}$ solutions (Velikova et al. 2000).

\section{POD (Peroxidase)}

The activity of POD (Peroxidase) was measured following the procedure established by Chance and Maehly (1955) by adding $100 \mu \mathrm{L}$ of the callus extract to $3 \mathrm{~mL}$ of assay solution, which contained $13 \mathrm{mM}$ guaiacol, $5 \mathrm{mM} \mathrm{H}_{2} \mathrm{O}_{2}$ and $50 \mathrm{Mm} \mathrm{Na}$-P buffer ( $\mathrm{pH} 6.5$ ). The POD (Peroxidase) activity was determined in absorbance at $470 \mathrm{~nm}$ of protein. The total soluble protein contents were determined by BCA (Bicinchoninic Acid) protocol (Yee et al. 2003; Erdal 2012).

\section{Sectioning with microtonal}


Having been kept in 10\% formaldehyde for 3 days, callus structures were taken to the cassettes and left for an overnight wash. Then, it was kept in 70, 80, 96\% ethyl alcohol, one hour apart, respectively. Absol-I, Absol-II, Xylol-I, and Xylol-II were kept for 1 hour, respectively. The calluses were embedded in parafilm, and a section of $6 \mu \mathrm{m}$ was taken (Rolls et al. 2012).

\section{Laser scanning confocal microscope (CLSM)}

Callus, sectioned with microton, are kept for about 30 minutes with $1 \%$ rhodamine. Then it is passed through distilled water 3 times. Fluorescence images were obtained with a Nikon Eclipse TE2000 Confocal Laser Scanning Microscope C1si. Samples were excited with the $488 \mathrm{~nm}$ line of an argon laser and dye emission was collected at 520 and $610 \mathrm{~nm}$. The DCF fluorescence was visualized in a single optical section of the callus. All images were obtained at the same depth (Minta et al. 1989).

\section{Scanning Electron Microscopy}

Alfalfa callus tissues were prefixed in $5 \%$ buffered glutaraldehyde ( $0.1 \mathrm{M}$ phosphate buffer, $\mathrm{pH} 7.2)$ for 2 $\mathrm{h}$ at room temperature. After dehydration through a graded ethanol series, samples were dried with a CPD (CO2 critical-point drying) system, sputter-coated with gold (Jeol JFC-1100 E ion-sputtering system) and observed with a scanning electron microscope (HITACHI S-4700).

\section{Statistical Analysis}

Each experiment was repeated three times. Analysis of variance was conducted using a one-way ANOVA test using SPSS 13.0 and means were compared by Duncan test at the 0.05 confidence level.

\section{Results}

\section{Green synthesis of Ca NPs}

\section{Characterization of $\mathrm{CaO}, \mathrm{CuO}$ and $\mathrm{ZnO} \mathrm{NPs}$}

Surface morphology examination of synthesized $\mathrm{CaO}, \mathrm{CuO}$ and $\mathrm{ZnO}$ NPs was carried out using Zeiss brand Sigma 300 model scanning electron microscope (SEM). From the SEM images given in Figure 1A, it can be seen that $\mathrm{CaO}$ NPs have a particle size ranging from 35 to $160 \mathrm{~nm}$. SEM images of $\mathrm{CaO}$ show that synthesized $\mathrm{CaO}$ NPs are porous, the structure is regular and has a very pleasant layered structure. When the SEM image of the obtained CuO NPs was examined (Figure 1B), it was determined that the CuO NPs were spherical and their dimensions were distributed between 20-45 nm (Gultekin et al, 2017; Gultekin et al. 2020). When the SEM images of ZnO NPs were examined (Figure 1C), it was determined that ZnO NPs were agglomerated and compatible with XRD results. It was observed that the structures of $\mathrm{ZnO}$ NPs were spherical and varying in size between $17-65 \mathrm{~nm}$. In addition, when the surfaces of $\mathrm{ZnO}$ NPs are rough, it is clearly seen from Figure $1 \mathrm{C}$. The findings obtained are also compatible with the literature (Rajendran and Sengodan 2017; Nadaroglu and Alayli 2020). 


\section{XRD analysis}

The spectra of the XRD analysis (X-ray diffraction) of the $\mathrm{CaO}$ NPs structure are shown in Figure 2. 28.75 ${ }^{\circ}$ indicates $34.16^{\circ}(111), 47.11 \circ, 50.86^{\circ}(311), 54.60^{\circ}(222), 62.60^{\circ}, \mathrm{Ca}^{2+}$ and carbohydrate units and $\mathrm{CaO}$ NPs (Sahu et al. 2017; Yazıcılar et al. 2021). The findings obtained confirmed that the structure of $\mathrm{CaO}$ NPs was successfully formed. XRD and crystallographic analysis of zinc nanoparticles by green synthesis method using walnut shell extract are given in Figure 3A. Characteristic peaks of the XRD spectrum that can be indexed at 2 fas $=11.390,22.240,36.090,49.220$, facets (111), (200), (220) are consistent with the literature. Zn NPs structures were determined to be cubic (fcc) zinc nanocrystals (Nadaroglu and Alayli 2020). XRD and crystallographic analysis of CuO nanoparticles synthesized by green synthesis method are given in Figure 2C. $2 \theta=32.20,39.620,58.90,70.30$ of the XRD spectrum showed characteristic peaks that can be indexed at facets (110), (111) and (202) (Figure 2C). It has been determined that CuO NPs structures have a spherical structure (Gultekin et al. 2020).

\section{MDA (Malondialdehyde)}

The callus induction stages of the Erzurum and Muş genotypes produced as a result of $\mathrm{ZnO}, \mathrm{CuO}$ and $\mathrm{CaO}$ NPs application against $\mathrm{NaCl}$ were evaluated. Also, salt-free $\mathrm{ZnO}, \mathrm{CuO}$ and $\mathrm{CaO}$ NPs applied callus formation stages were evaluated. Table 1. clearly display that MDA activities were greatly affected in callus formation stage of two alfalfa lines in presence of $0.8 \mathrm{ppm}$ NPs after salt treatments. MDA values indicated a large range of variation among tested samples for salt stress treatments, ranging from 0,0168 to $0,0466 \mathrm{nmol} \mathrm{g}^{-1} \mathrm{FW}$. The maximum activity was observed from callus treated of $50 \mathrm{mM} \mathrm{NaCl}$ with 0.8 ppm CuO NPs. The callus induction stage without salt treatments indicated a best result in $0.8 \mathrm{ppm} \mathrm{CaO}$ NPs for MDA value compared to the other NPs. Although the highest membrane damage was found in the treatments with $0.8 \mathrm{ppm} \mathrm{CuO} 50 \mathrm{mM} \mathrm{NaCl}$ in callus induction stage, the lowest membrane damage was found in 'callus formation stage' for 0.8 ppm CaO NPs $50 \mathrm{mM} \mathrm{NaCl}$ (Table 1).

\section{$\mathrm{H}_{2} \mathrm{O}_{2}$ (Hydrogen peroxide)}

There were significantly differences among 1 . week Muş callus and the other groups (Fig. 2). Table 1 clearly display that $\mathrm{H}_{2} \mathrm{O}_{2}$ activities were significantly affected in the tested callus of two alfalfa lines in presence of 0.8 ppm NPs. $\mathrm{H}_{2} \mathrm{O}_{2}$ values indicated a large range of variation among tested samples for salt stress treatments, ranging from 0,0134 to $0,0979 \mathrm{nmol} \mathrm{g}^{-1} \mathrm{FW}$. The callus induction stage without salt treatments indicated a best result in $0.8 \mathrm{ppm} \mathrm{CaO} \mathrm{NPsfor} \mathrm{H}_{2} \mathrm{O}_{2}$ value compared to the other NPs. Although the highest membrane damage was found in the treatments of $0.8 \mathrm{ppm}$ CuO NPs in the callus induction stage, the lowest membrane damage was found in callus formation stage for $0.8 \mathrm{ppm} \mathrm{CuO}$ NPs (Table 1).

\section{POD (Peroxidase)}

Table 1 clearly display that POD activities were significantly affected in callus formation stage of two alfalfa lines in presence of 0.8 ppm NPs. POD values indicated a large range of variation among tested 
samples for salt stress treatments, ranging from 0,1035 to $1,666 \mathrm{nmol} \mathrm{g}{ }^{-1} \mathrm{FW}$. The maximum activity was observed from callus treated of $50 \mathrm{mM} \mathrm{NaCl}$. The callus induction stage without salt treatments indicated a best result in $0.8 \mathrm{ppm} \mathrm{CaO} \mathrm{NPs} \mathrm{for} \mathrm{POD} \mathrm{value} \mathrm{compared} \mathrm{to} \mathrm{the} \mathrm{other} \mathrm{NPs.} \mathrm{Although} \mathrm{the} \mathrm{highest}$ membrane damage was found in the treatments of $50 \mathrm{mM} \mathrm{NaCl}$, the lowest membrane damage was found in 'callus induction stage' for 0.8 ppm CuO NPs (Table 1).

\section{Protein Analysis}

The analysis displayed that protein levels have stronger effects in the Muş and Erzurum callus (Fig. 6). However, few accumulations of protein were detected in the control callus except $0.8 \mathrm{ppm}$ CuO. CuO displayed lower protein accumulation prior to $\mathrm{NaCl}$. The best response was obtained from callus induction stage and callus formation stage after $50 \mathrm{mM}$ treatment $\mathrm{NaCl}$ with $0.8 \mathrm{ppm} \mathrm{CuO}$. The best response was obtained from callus induction stage and callus formation callus without $\mathrm{NaCl}$ with 0.8 ppm ZnO (Table 1).

\section{Laser Scanning Confocal Microscope (LSCM)}

LSCM was used as a visual marker to verify the distribution of nanoparticles in stable callus culture. $\mathrm{NaCl}$ free callus and callus which applied the $50 \mathrm{mM} \mathrm{NaCl}$ alone were used as a control. The analysis displayed that the $\mathrm{CaO}, \mathrm{CuO}$ and $\mathrm{ZnO}$ NPs are obviously traceable in the Erzurum and Muş callus tissues. However, The $\mathrm{NaCl}$ stress inhibited in terms of nanoparticles was at different degrees. CuO exhibited a better response than $\mathrm{CaO}$ and $\mathrm{ZnO}$ NPs in response to $\mathrm{NaCl}$ stress. In the first week, accumulation of NPs inside the cell was lower activity by $\mathrm{NaCl}$ than in the second week in terms of Erzurum and Muş genotype. According to the result of the confocal analysis, $\mathrm{CuO}$ exhibited the most abundant callus induction stage, followed by $\mathrm{ZnO}$ exhibited at callus induction stage, $50 \mathrm{mM} \mathrm{NaCl} \mathrm{ZnO}$ callus induction stage and finally, $50 \mathrm{mM} \mathrm{NaCl} \mathrm{CuO}$ callus induction stage (Fig. 7).

\section{SEM analysis of callus structures}

SEM detection indicated that each genotype callus type had various callus structures. There was a continuous amorphous sphere, termed extracellular matrix, on the callus surface. It was also detected that cultivars belonging to the same genotypes share similar cell structure and shapes. The soft and compact character of the callus in Erzurum and Muş convert to granular- mucilage resembles, mostly likes a membranous surface and wrinkled cell mass structure under SEM detections (Fig. 8).

\section{Discussion}

Alfalfa is an important high nutritional feeding quality and $\mathrm{N}$ fixation, which have a great potential for wildlife habitat and soil conservation. However, abiotic stress such as salinity which causes adverse effects on germination, plant vigour and crop yield, thereby affecting annual development and resulting in serious economic losses (Sakiroglu and Brummer 2017). Various cultural and chemical control strategies have been attempted to address these concerns, but the strategies were only partially powerful. In 
comparison, nanotechnology supplied new options to produce resistance plants against abiotic stress factors (Iqbal et al. 2020; Gohari et al. 2020). In fact, many studies have been reported on the plant species use of nanoparticles in response to stress factors. In this study, in vitro callus induction responses of alfalfa under $\mathrm{NaCl}$ and $\mathrm{CaO}, \mathrm{CuO}, \mathrm{ZnO}$ were examined and present study displayed significant differences in their responses to the NPs. The results indicated that NPs had a promoting effects callus induction, while control callus postponed the day of callus induction. It was detected that with treatment NPs the degree of callus induction also highly increased. The obtained results that compact callus with globular structure and yellowish colour callus were formed from leaf explants within 1 months, while there was callus induction in the NPs within a shorter time 1 months. Callus were induction in NPs treatments with various frequencies. The highest frequency of callus induction from leaf explant of Muş genotype was detected on the medium containing $0.8 \mathrm{ppm} \mathrm{CaO}$. Among tested treatments, $\mathrm{CaO}$ is evident to be higher effective than $\mathrm{CuO}, \mathrm{ZnO}$ in callus induction from leaf explants. The fresh weight in Muş callus in the presence of $0.8 \mathrm{ppm} \mathrm{CaO}$ was heavier than those of $\mathrm{CuO}$ and $\mathrm{ZnO}$ in equal concentration (data not shown). It was proved that considerable uptake and accumulation of the nutrient elements occurred. Noticeably the size all tested NPs examined in this study did identical, with a value of $20-160 \mathrm{~nm}$ but varying uptake and accumulation functions of those three types of NPs were detected, and the genotype dependent uptake for NPs occured in the callus. Previous studies have shown a positive correlation between $\mathrm{NaCl}$ and nanoparticules accumulation in various plant species (Wang et al. 2019; Javed et al. 2017). $\mathrm{Ca}^{2+}$ ions are rapidly carried by membrane channels that are available on the plasma surface (Berridge et al. 2000; Ditta and Arshad 2016; Liu et al. 2016). This obviously confirms that $\mathrm{CaO}$ in the culture medium was quickly responsive and effective accumulation. In terms of confocal analysis, assessment of NPs functions in the presence of $\mathrm{NaCl}$ was based on the expanded coloration, tissue damage, and amount of the cell survival. In our cases, the results of laser scanning confocal analysis and SEM demonstrate the delivery of NPs alfalfa callus is supported related to the uptake of nutrient elements and translocate from culture medium (Fig. 7). CuO nanoparticle application in the Muş genotype at the $1^{\text {st }}$ week provided an expected improvement on $\mathrm{NaCl}$ stress. $\mathrm{CuO}$ application showed a dense distribution in the cell by preventing the adverse effect of $50 \mathrm{mM}$ salt faster than $\mathrm{ZnO}$ and $\mathrm{CaO}$ application. The best reponse of $\mathrm{ZnO}$ nanoparticle application was obtained in the $2^{\text {nd }}$ week of the Muş genotype compared with the $1^{\text {st }}$ week and the $2^{\text {nd }}$ week. $\mathrm{ZnO}$ accumulated intensely in certain parts of the cell in $1^{\text {st }}$ week application, and as the period extended, it simultaneously distributed into the cell and prevented the negative effect of salt. These indicate that term alterations of defense responses to $\mathrm{NaCl}$ could be a main process. One or two weeks post $\mathrm{NaCl}$ application, control callus displayed salt severity on the callus tissues, resulting in a tissue damage within less than 7 days (Fig 7). By contrast, Muş and Erzurum genotypes are $1^{\text {st }}$ application CuO NPs survived longer than 2 weeks, indicating considerably improved resistance to $\mathrm{NaCl}$. Our detection of NPs in callus tissues following a fairly aggressive $2^{\text {nd }}$ applications suggests that $\mathrm{CaO}, \mathrm{CuO}$ and $\mathrm{ZnO}$ was present, not merely on the extracellular matrix, but that it penetrated inside the callus cells. SEM analysis supported with confocal analysis results in indicating that $\mathrm{CuO}$ was distrupted the extracellular matrix of alfalfa callus 7 days post exposure (Fig 7c). 14 days post exposure, $\mathrm{CuO}$ was clearly located inside callus cell tissues. It was 
detected that the formation of callus structure of alfalfa callus subject to media including various NPs such as $\mathrm{CaO}, \mathrm{CuO}$ and $\mathrm{ZnO}$ can be added to the culture media. It was noticed that no harmful for cell wall in callus of the control while harmfuls were detected in cell wall of callus exposure to $50 \mathrm{mM} \mathrm{NaCl}$. This is evident that even lower doses $\mathrm{NaCl}$ dramatically increased on the harmful cell wall of the callus tissues. $\mathrm{CaO}, \mathrm{CuO}$ and $\mathrm{ZnO}$ influence for induction $\mathrm{NaCl}$ stress various concentrations of $\mathrm{NaCl}$. Callus produces an amorphous mass of extreme cell wall in response to exposure to different time-periods (Fig. 8). Accumulation nanoparticles and its adverse effects on applied callus tissues highly depend upon the genotype and exposure time. For example; 7 days post exposure, ZnO NPs exhibited membranous structures to be extracellular matrix and related to neighboring cells, and they were intensely $\mathrm{ZnO}$ that accumulated and present in the $50 \mathrm{mM} \mathrm{NaCl}$. In contrast, CuO NPs showed partial rough and mucilagelike on the fibroblast in Erzurum genotypes. Although the $\mathrm{CaO}$ NPs exhibited wrinkle and rough structures at $1^{\text {st }}$ week of Erzurum genotype. In $1^{\text {st }}$ week of the application of $50 \mathrm{mM} \mathrm{NaCl}$ of $\mathrm{Muş}$ genotype mostly granular structures and nodular callus segments were showed. Interestingly the CaO NPs exhibited mucilage-like structures and differentiation of calllus primordia at $2^{\text {nd }}$ week of Muş genotype and $2^{\text {nd }}$ week of the application of $50 \mathrm{mM} \mathrm{NaCl}$ of Erzurum genotype wrinkle structures were shown (Fig. 8). Obviously, $\mathrm{CaO}, \mathrm{ZnO}$ and $\mathrm{CuO}$ are greatly reactive and are able to pass through the cell membrane in both cases and recover the callus from $\mathrm{NaCl}$ stress. It is evident that callus exposed to $\mathrm{NaCl}$ in the $2^{\text {nd }}$ week will provide higher physiological properties regardless of nanoparticule types which are linked to the regeneration capacity in callus cells. This verifies us that chemical composition and structural regulating on the callus tissues might play important functions in morphological formation. Medium conditions in tissue culture induced activation of various cellular defense strategies, adjusting cell adaptation under new environmental conditions. These findings are consistent with one of the first reports on formation of the ECM mediated on the outer surface layer (Zari et al. 2015). They suggested that ECM formation might be a stress response of explants, revealed by specific tissue culture conditions. $\mathrm{NaCl}$ severity resulted in an obvious increase in MDA values in callus. A reduction of MDA was also observed in callus formation stage subject to $0.8 \mathrm{ppm} \mathrm{CaO} 50 \mathrm{mM} \mathrm{NaCl}$ period. Based on genotype, the NPs applied callus had considerably higher MDA values compared with $1^{\text {st }}$ and $2^{\text {nd }}$ weeks. This indicated that $\mathrm{NaCl}$-activated stress severity was alleviated by $\mathrm{ZnO}, \mathrm{CuO}$ and $\mathrm{CaO}$ (Fig. 3). These results indicated that the effect of NPs was linked to the callus structure and genotypes. These findings are in agreement with one of the reports in absence of NPs mediated tolerance to $\mathrm{NaCl}$ stress potato callus (Rizwan et al. 2015). Levels of MDA in callus induction stages higher activity than callus formation stage in callus cells of both genotypes. The obtained results suggested that MDA activity from callus induction stage was higher promoting NPs uptake and binding capacity in the cytosol even without $\mathrm{NaCl}$. This verifying that the $\mathrm{NaCl}$ induced stress was mitigated by nano-Cao, $\mathrm{CuO}$ and $\mathrm{ZnO}$. Under stress conditions, $\mathrm{H}_{2} \mathrm{O}_{2}$ is generated and mediates crosstalk among metabolic process. Therefore, the $\mathrm{H}_{2} \mathrm{O}_{2}$ is a likely signaling molecule that participates to the events (Soleymanzadeh et al. 2020). In our cases, the results verified that the production of $\mathrm{H}_{2} \mathrm{O}_{2}$ is dependent on genotype and nanoparticules types and this was confirmed by the statistical test. However, application of Muş genotype with $1^{\text {st }}$ week was significantly different from $2^{\text {nd }}$ week as well as Erzurum genotype. and there was higher $\mathrm{H}_{2} \mathrm{O}_{2}$ production at the callus formation stage in the presence of $\mathrm{CuO}$ 
NPs. Additionally, Application of long period callus cells with $\mathrm{CuO}$ considerably recovered stress severity at callus formation stage (Fig. 4). These results are contributed with the outcomes obtained on callus cells tissues in different Triticale genotypes (Yazıcılar et al. 2021). The POD activity with NPs in callus tissues was considerably decreased exposed control and in presence of $50 \mathrm{mM} \mathrm{NaCl}$. Moreover; The results of this study displayed that calli decreased callus formation stages that the POD decreased; and these decreases were seen to have changed depending on the genotypes, type and period of the nanoparticules applied. This decrease was detected changeable depending on the applied NPs period. Although the maximum POD activity was recorded at in presence of $\mathrm{NaCl}$, the minimum POD activity was recorded at $0.8 \mathrm{ppm} \mathrm{CuO} \mathrm{callus} \mathrm{formation} \mathrm{stage} \mathrm{(Fig.} \mathrm{5).} \mathrm{Based} \mathrm{on} \mathrm{our} \mathrm{findings,} \mathrm{decreases} \mathrm{in} \mathrm{POD} \mathrm{activity}$ in NPs-treated callus could be linked to promotion of callus development parameters and protective role of NP as direct or indirect. Additionally; Induction in POD activity may be explained that $\mathrm{Cu}^{+2}$ ions led to higher ROS generation, and initially promoted their antioxidant system to challenge the ROS but then lost capacity to regulate antioxidant enzyme activity. This is consistent with the earlier report indicating that POD activity is greatly linked to NPs ions. (Liang et al. 2018; Castiglione et al. 2014). It is evident that organs and tissues of plants exposed to environmental stress in long-term will gradually lose their biochemical and enzymatical structures. $1^{\text {st }}$ week Muş applications exhibited an enough activity of POD that mainly due to rapid and efficient inducer of $\mathrm{CuO}$ NPs, whereas $\mathrm{ZnO}$ was slowly effective, which could probably be an outcome of stronger stability of $\mathrm{ZnO}$. Stability is a main strategy determining the transformation, transport, fate, and toxicity of ZnO NPs in various growth media. This can be explained that the behavior of NPs depends on the intrinsic physiochemical properties and the chemistry of the surrounding different environment media. The nanoparticules uptake mechanisms can be influenced by several factors including salinity, total organic carbon, $\mathrm{pH}$, redox potential, water properties like ionic strength, natural organic material (NOM), redox potential, and other chemical components influence the short- and long-term behavior of CuO NPs (Sousa and Texeira 2013; Conway et al. 2015). Applied longterm cultured callus cells with $0.8 \mathrm{ppm}$ NPs exhibited the best response and considerably recovered ZnO $\mathrm{NPs}$ as compared to control callus in terms of protein content. After $\mathrm{NaCl}$ exposure, $\mathrm{ZnO}$ was found to be hardly recovered at callus induction stage and callus formation stage in response to $\mathrm{NaCl}$ stress as compared to $50 \mathrm{mM} \mathrm{NaCl}$ and control callus (Fig. 6). This explains that ZnOuptake, translocation and accumulation of ZnO-NPs by plants depend upon the distinct features of the NPs as well as on the physiology of the host plant. This can be attributed to that the effects of $\mathrm{ZnO}$ on callus cells may be dependent concentrations and strong systemic activity of the $\mathrm{Zn}^{+2}$ ions. These results were similar with an earlier report on expression in response to ZnO uptake (Lorez-Moreno et al. 2010; Zhao et al. 2012). The uptake and biotransformation of ZnO NPs in plants are not only related concentrations but also particle adhesion onto cell surface, therefore $\mathrm{ZnO}$ uptake may also arise due to particle dissolution in the culture medium. This suggested that the callus cells were slightly effective at $\mathrm{NaCl}$ severity in $0.8 \mathrm{ppm}$ $\mathrm{ZnO}$ applied. As explained above, $\mathrm{CuO}$ was more effective than $\mathrm{ZnO}$ on callus cells in response to $\mathrm{NaCl}$ severity. It is well-known that callus cells within explant resources demonstrate intensive cell division and hence there is necessary for active synthesis of nucleic acids. Need for DNA production improves the synthesis of NTP. That is an early substrate for nucleic acid synthesis. Increased NTP synthesis increases $\mathrm{pH}$ level within cells. This statement confirms that protein synthesis is significant for plant growth and 
development, which are highly sensitive to the $\mathrm{NaCl}$ stress. The result may have verified by the microscopy studies with a SEM in which display a reduction in the formation of continous surface in presence of of $\mathrm{ZnO}$ NPs. In fact, by extending the period $\mathrm{ZnO}$, the formation of membranous structures as well as some wrinkle and amorphous compounds were detected. These effects are likely due to synthesis protein and inducing structural changes in protein and thus the formation of various conformational changes in the callus surfaces.

\section{Conclusions}

It was observed that $\mathrm{NaCl}$ resulted in altered pattern of $\mathrm{CuO}$ and $\mathrm{ZnO}$ in the callus tissues of the two alfalfa genotypes. $\mathrm{NaCl}$ tolerance in alfalfa can be improve by increase in NPs uptake efficiency. Moreover; callus induction stage in presence of $\mathrm{CaO}$ were affected but did not appear to have expected positive relationship with antioxidant enzyme activities under $\mathrm{NaCl}$. It is inferred from the outcomes of the present study that decreased the adverse affects of $\mathrm{NaCl}$ on alfalfa callus tissues through improving MDA, $\mathrm{H}_{2} \mathrm{O}_{2}$ and protein rates and lowering the activity of POD in presence of NPs. In the near future; these $\mathrm{CaO}, \mathrm{CuO}$ and $\mathrm{ZnO}$ can be application to the callus tissues of other plant species that improve to other abiotic stress factors.

\section{Declarations}

Author contributions Concept-IB; Design-IB and BY; Supervision-IB; Resource-IB; Materials-BY, FB, MŞ, HN and AA; Data Collection and/or Processing-MŞ and BY; Analysis and/or Interpretation- BY, FB and MŞ; Literature Search-BY and MŞ; Writing-IB; Critical Reviews-HN and AA.

\section{Compliance with ethical standards}

Conflict of interest The authors have declared that no conflict of interests exists.

\section{References}

1. Alabdallah NM, Alzahrani HS (2020) The potential mitigation effect of $\mathrm{ZnO}$ nanoparticles on [Abelmoschus esculentus L. Moench] metabolism under salt stress conditions. Saudi Journal of Biological Sciences 27(11):3132-3137

2. Berridge MJ, Lipp P, Bootman MD (2000) The versatility and universality of calcium signalling. Nat Rev Mol Cell Biol 1:11-21

3. Bezirganoglu I (2017) Response of five triticale genotypes to salt stress in in vitro culture. Turkish Journal of Agriculture and Forestry 41(5):372-380

4. Castiglione MR, Giorgetti L, Cremonini R, Bottega S, Spano 2014 Impact of TiO2 nanoparticles on Vicia narbonensis L.: potential toxicity effects Protoplasma 251(6): DOI: 10.1007/s00709-014-06495

5. Chance B, Maehly AC (1955) Assay of catalase and peroxidase. Methods Enzymol 2:764-775 
6. Conway JR, Adeleye AS, Gardea-Torresdey J, Keller AA (2015) Aggregation, Dissolution, and Transformation of Copper Nanoparticles in Natural Waters. Environ Sci Technol 49:2749-2756

7. Dimpka CO, McLean JE, Latta DE, Manangón E, Britt DW, Johnson WP, Maxim IB, Anderson AJ (2012) $\mathrm{CuO}$ and $\mathrm{ZnO}$ nanoparticles: phytotoxicity, metal speciation, and induction of oxidative stress in sand-grown wheat. Journal of Nanoparticle Research 14(9):1-15

8. Ditta A, Arshad M (2016) Applications and perspectives of using nanomaterials for sustainable plant nutrition. Nanotechnology Reviews 5(2)

9. Elmaghrabi A, Ochatt S (2006) Isoenzymes and flow cytometry for the assessment of true-totypeness of calluses and cell suspensions of barrel medic prior to regeneration. Plant Cell, Tissue and Organ Culture 85(1):31-43

10. Erdal S (2012) Androsterone-induced molecular and physiological changes in maize seedlings in response to chilling stress. Plant Physiol Biochem 57:1-7

11. Gao S, Yang L, Zeng HQ, Zhou ZS, Yang ZM, Li H, Zhang B (2016) A cotton miRNA is involved in regulation of plant response to salt stress. Scientific Reports 6(1):1-14

12. Gohari G, Mohammadi A, Akbari A, Panahirad S, Dadpour MR, Fotopoulos V, Kimura S (2020) Titanium dioxide nanoparticles (TiO2 NPs) promote growth and ameliorate salinity stress effects on essential oil profile and biochemical attributes of Dracocephalummoldavica. Sci Rep 10(1):1-14

13. Gultekin DD, Alaylı A, Nadaroglu H (2020) Eco-friendly synthesis of nano copper and its use in fenton-like reactions for methylene blue degradation. International Journal of Chemistry and Technology 4(1):71-78

14. Gultekin DD, Gungor AA, Onem H, Babagil A, Nadaroglu H (2016) Synthesis of copper nanoparticles using a different method: determination of its antioxidant and antimicrobial activity. Journal of the Turkish Chemical Society Section A: Chemistry 3(3):623-636

15. Heath RL, Packer L (1968) Photoperoxidation in isolated chloroplasts: I. Kinetics and stoichiometry of fatty acid peroxidation. Archives of Biochemistry and Biophysics 125(1):189-198

16. Iqbal MS, Singh AK, Singh SP, Ansari MI (2020) Nanoparticles and plant interaction with respect to stress response. In Nanomaterials and Environmental Biotechnology, pp 1-15

17. Jaleel CA, Sankar B, Sridharan R, Panneerselvam R (2007) Soil salinity alters growth, chlorophyll content, and secondary metabolite accumulation in Catharanthus roseus. Turk J Biol 32:79-83

18. Jalili B, Bagheri B, Azadi S, Soltani J (2019) Identification and salt tolerance evaluation of endophyte fungi isolates from halophyte plants. International Journal of Environmental Science and Technology 17:3459-3466

19. Jalili F, Khavazi K, Pazira E, Nejati A, Rahmani HA, Sadaghiani HR (2009) Isolation and characterization of ACC deaminase-producing fluorescent Pseudomonads, to alleviate salinity stress on canola (Brassica napus L.) growth. J. Plant Physiol 166:667-674

20. Javed R, Usman M, Yücesan B, Zia M, Gürel E (2017) Effect of zinc oxide (ZnO) nanoparticles on physiology and steviol glycosides production in micropropagated shoots of Stevia rebaudiana Bertoni. Plant Physiol Biochem 110:94-99 
21. Ji YH, Zhang H, Zhang K, Li G, Lian S, Cheng ZB, Zhou YJ (2013) First Report of Tomato yellow leaf curl virus in Acalypha australis in China. Plant Dis 97(3):430-430

22. Kim DH, Gopal J, Sivanesan I (2017) Nanomaterials in plant tissue culture: the disclosed and undisclosed. RSC Advances 7(58):36492-36505

23. Lian M, Wang J, Sun L, Xu Z, Tang J, Yan J, Zeng X (2019) Profiles and potential health risks of heavy metals in soil and crops from the watershed of Xi River in Northeast China. Ecotoxicol Environ Saf (169) 442-448

24. Liang W, Ma X, Wan P, Liu L (2018) Plant salt-tolerance mechanism: A review. Biochem Biophys Res Commun 495(1):286-291

25. Liu RH, Kang YH, Pei L, Wan SQ, Liu SP, Liu SH (2016) Use of a new controlled-loss-fertilizer to reduce nitrogen losses during winter wheat cultivation in the Danjiangkou Reservoir Area of China. Commun Soil Sci Plant Anal 47:1137-1147

26. López-Moreno ML, de la Rosa G, Hernández-Viezcas JA, Castillo-Michel H, Botez CE, Peralta-Videa JR, Gardea-Torresdey JL (2010) Evidence of the Differential Biotransformation and Genotoxicity of $\mathrm{ZnO}$ and $\mathrm{CeO}_{2} \mathrm{Nanoparticles} \mathrm{on} \mathrm{Soybean} \mathrm{(Glycine} \mathrm{max)} \mathrm{Plants.} \mathrm{Environmental} \mathrm{Science} \mathrm{\&} \mathrm{Technology}$ 44(19):7315-7320

27. Manchanda G, Garg N (2008) Salinity and its effects on the functional biology of legumes. Acta Physiologiae Plantarum 30(5):595-618

28. Minta A, Kao JP, Tsien RY (1989) Fluorescent indicators for cytosolic calcium based on rhodamine and fluorescein chromophores. Biol Chem 15(14):8171-8178

29. Murashige T, Skoog F (1962) A revised medium for rapid growth and bio assays with tobacco tissue cultures. Physiologia plantarum 15(3):473-497

30. Nadaroglu H, Alaylı Gungor A (2020) Highly sensitive glucose sensor based on ZnO NPs as a biomimetic enzyme. Bioscience Research 17(2):775-785

31. Nadaroglu H, Alaylı Güngör A, Ince S (2017) Synthesis of nanoparticles by green synthesis method. Int J Innov Res Rev 1(1):6-9

32. Parida AK, Das AB (2005) Salt tolerance and salinity effects on plants. Ecotoxicol Environ Saf 60(3):324-349

33. Parihar P, Singh S, Singh R, Singh VP, Prasad SM (2015) Effect of salinity stress on plants and its tolerance strategies:a review. Environmental Science and Pollution Research 22(6):4056-4075

34. Putnam D, Russelle M, Orloff S, Kuhn J, Fitzhugh L, Godfrey L, Long R (2001) Alfalfa, wildlife and the environment. The importance and benefits of alfalfa in the 21 st century

35. Rajendran SP, Sengodan K (2017) Synthesis and characterization of zinc oxide and iron oxide nanoparticles using Sesbania grandiflora leaf extract as reducing agent. Journal of Nanoscience 1-7

36. Rizwan M, Ali S, Ibrahim M, Farid M, Adrees M, Bharwana SA, Rehman MZ, Qayyum MF, Abbas F (2015) Mechanisms of siliconmediated alleviation of drought and salt stress in plants: a review. Environ Sci Pollut Res 22:15416-15431 
37. Rolls GO, Farmer NJ, Hall JB (2012) Melbourne (Australia): Leica Biosystems Pty LTD. Artefacts in Histological and Cytological Preparations, p 106

38. Ruttkay-Nedecky B, Krystofova O, Nejdl L, Adam V (2017) Nanoparticles based on essential metals and their phytotoxicity. Journal of Nanobiotechnology 15(1):1-19

39. Sahu G, Saha S, Datta S, Chavan P, Naik S (2017) Methanolysis of Jatropha curcas oil using $\mathrm{K} 2 \mathrm{CO} / \mathrm{CaO}$ as a solid base catalyst. Turkish Journal of Chemistry 41(6):845-861

40. Sakiroglu M, Brummer EC (2017) Identification of loci controlling forage yield and nutritive value in diploid alfalfa using GBS-GWAS. Theoretical and Applied Genetics 130(2):261-268

41. Sergiev I, Alxieva V, Karanov E (1997) Effect of spermone, atrazine and combination between them on some endogenous protective systems and stress markers in plants. Comp Rend Acad Bulg Sci 51:121-124

42. Soleymanzadeh R, Iranbakhsh A, Habıbı G, Ardebılı ZO (2020) Selenıum nanopartıcle protected strawberry against salt stress through modifications in salicylic acid, ion homeostasis, antioxidant machinery, and photosynthesis performance. Acta Biologica Cracoviensia Series Botanica 62/1: 3342

43. Sousa VS, Teixeira MR (2013) Aggregation kinetics and surface charge of CuO nanoparticles: the influence of pH, ionic strength and humic acids. Environmental Chemistry 10(4):313-322

44. Velikova V, Yordanov I, Edreva A (2000) Oxidative stress and some antioxidantsystems in acid raintreated bean plants protective role of exogenous polyamines. Plant Sci 151:59-66

45. Vijayakumar PS, Abhilash OU, Khan BM, Prasad BL (2010) Nanogold-Loaded Sharp-Edged Carbon Bullets as Plant-Gene Carriers. Advanced Functional Materials 20(15):2416-2423

46. Wang P, Lombi E, Zhao FJ, Kopittke PM (2016) Nanotechnology: a new opportunity in plant sciences. Trends in Plant Science 21(8):699-712

47. Wang Z, Li H, Li X, Xin C, Li S, Li Y, Zheng X, Li H, Wei X, Zhang Z, Kong L, Wang F (2019) Naomo-ZnO priming induces salt tolerance by promoting photosynthetic carbon assimilation in wheat. Archies of Agronomy and Soil Science 1259-1273

48. Yazıcılar B, Böke F, Alaylı A, Nadaroglu H, Gedikli S, Bezirganoglu I (2021) In vitro effects of CaO nanoparticles on Triticale callus exposed to short and long-term salt stress. Plant Cell Reports 1-14

49. Yee Y, Tam NFY, Wong YS, Lu CY (2003) Growth and physiological responses of two mangrove species (Bruguiera gymnorrhiza and Kandelia candel) to water logging. Environ Exp Bot 49(3):209221

50. Zari H, Babak P, Asad R (2015) The Effect of Priming with Nano-sliver on Agronomic Traits of Safflower Cultivars. Journal of Essential Oil Bearing Plants 18(5):1148-1156

51. Zhao L, Hernandez-Viezcas JA, Peralta-Videa JR, Bandyopadhyay S, Peng B, Munoz B, Keller AA, Gardea-Torresdey JL (2012) ZnO nanoparticle fate in soil and zinc bioaccumulation in corn plants (Zea mays) influenced by alginate. Enviromental Science: Processes Impacts 15(1):260-266 
52. Zhu T, Deng X, Zhou X, Zhu L, Zou L, Li P, Zhang D, Lin H (2016) Ethylene and hydrogen peroxide are involved in brassinosteroid-induced salt tolerance in tomato. Scientific Reports 6:35392

\section{Tables}

Due to technical limitations, table 1,2 is only available as a download in the Supplemental Files section.

\section{Figures}

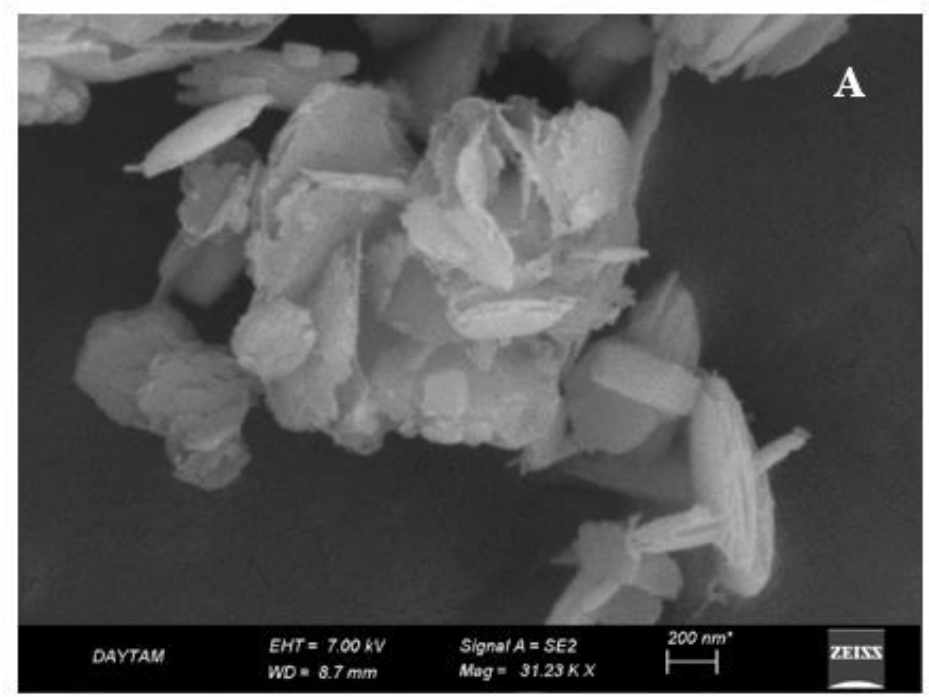

$\mathrm{CaO}$

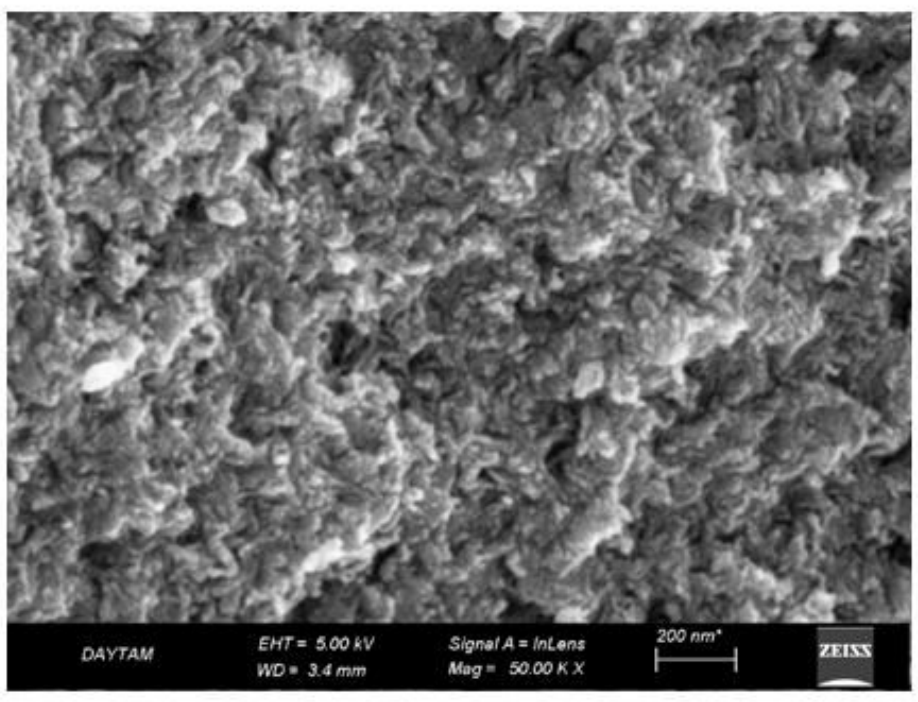

$\mathrm{ZnO}$

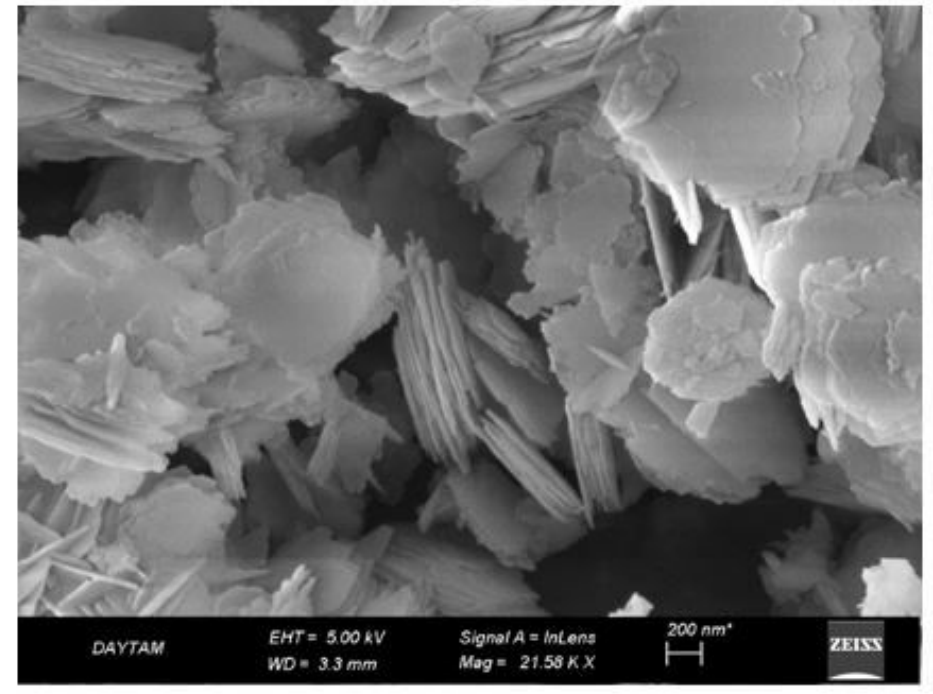

$\mathrm{CaO}$

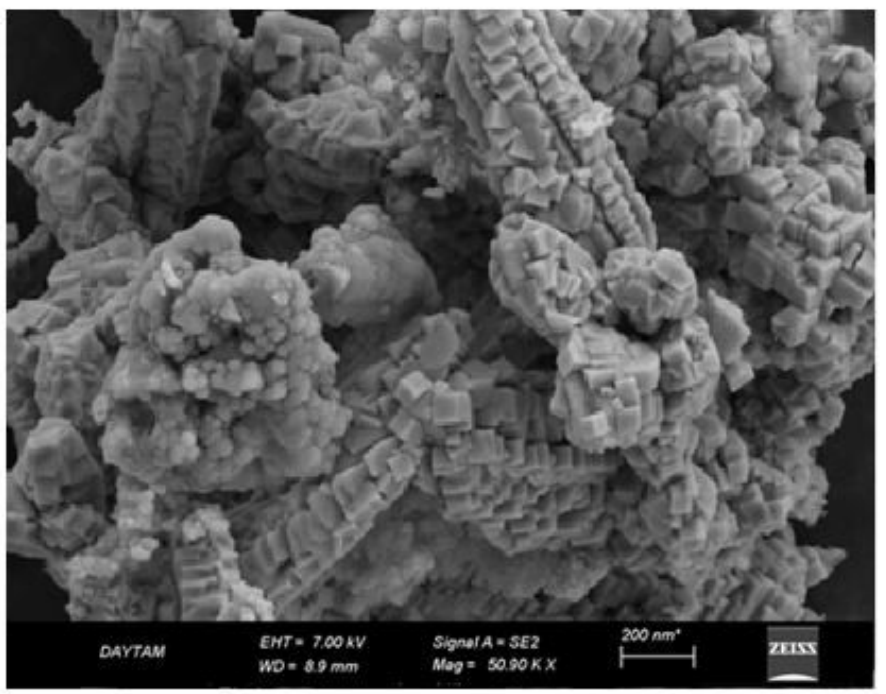

$\mathrm{CuO}$

Figure 1 
SEM images of $\mathrm{CaO}$ NPs (A), ZnO NPs (B) and CuO NPs (C)
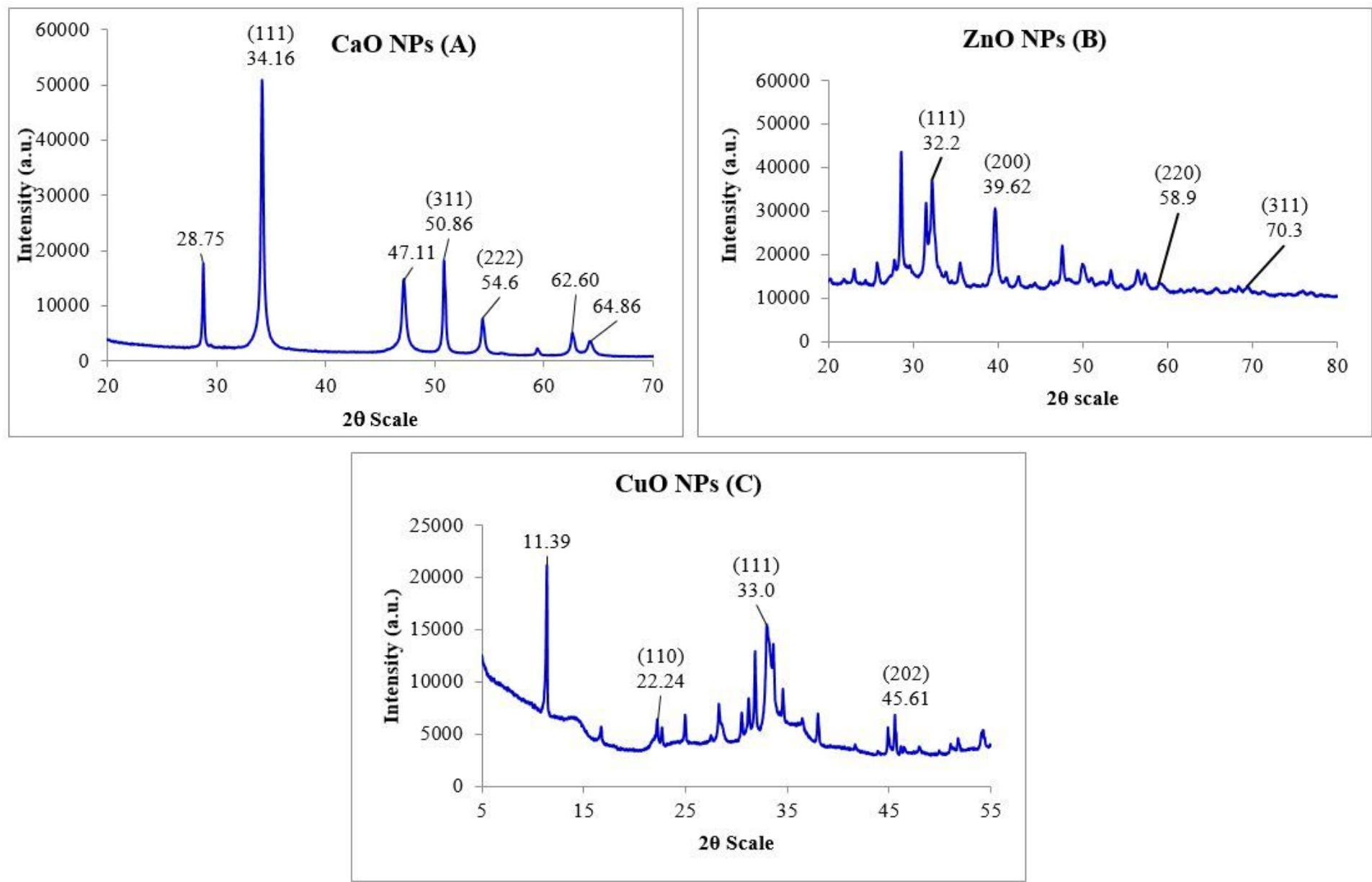

Figure 2

XRD patterns of $\mathrm{CaO}$ NPs (A), ZnO NPs (B) and $\mathrm{CuO}$ NPs (C) 


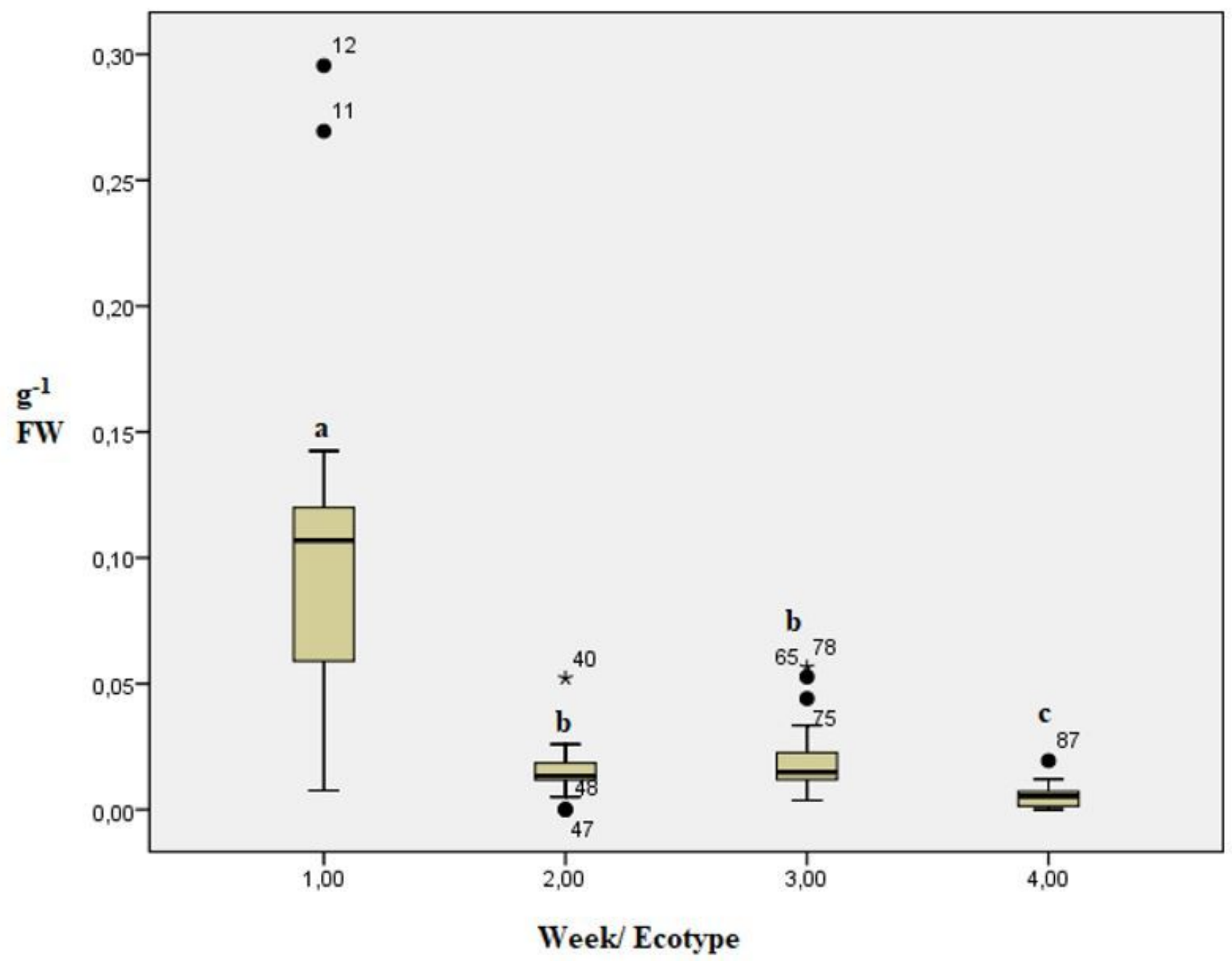

Figure 3

Changes in MDA acitivity alfalfa genotypes: 1: First week Muş, 2: First week Erzurum, 3: Second week Muş, 4: Second week Erzurum 


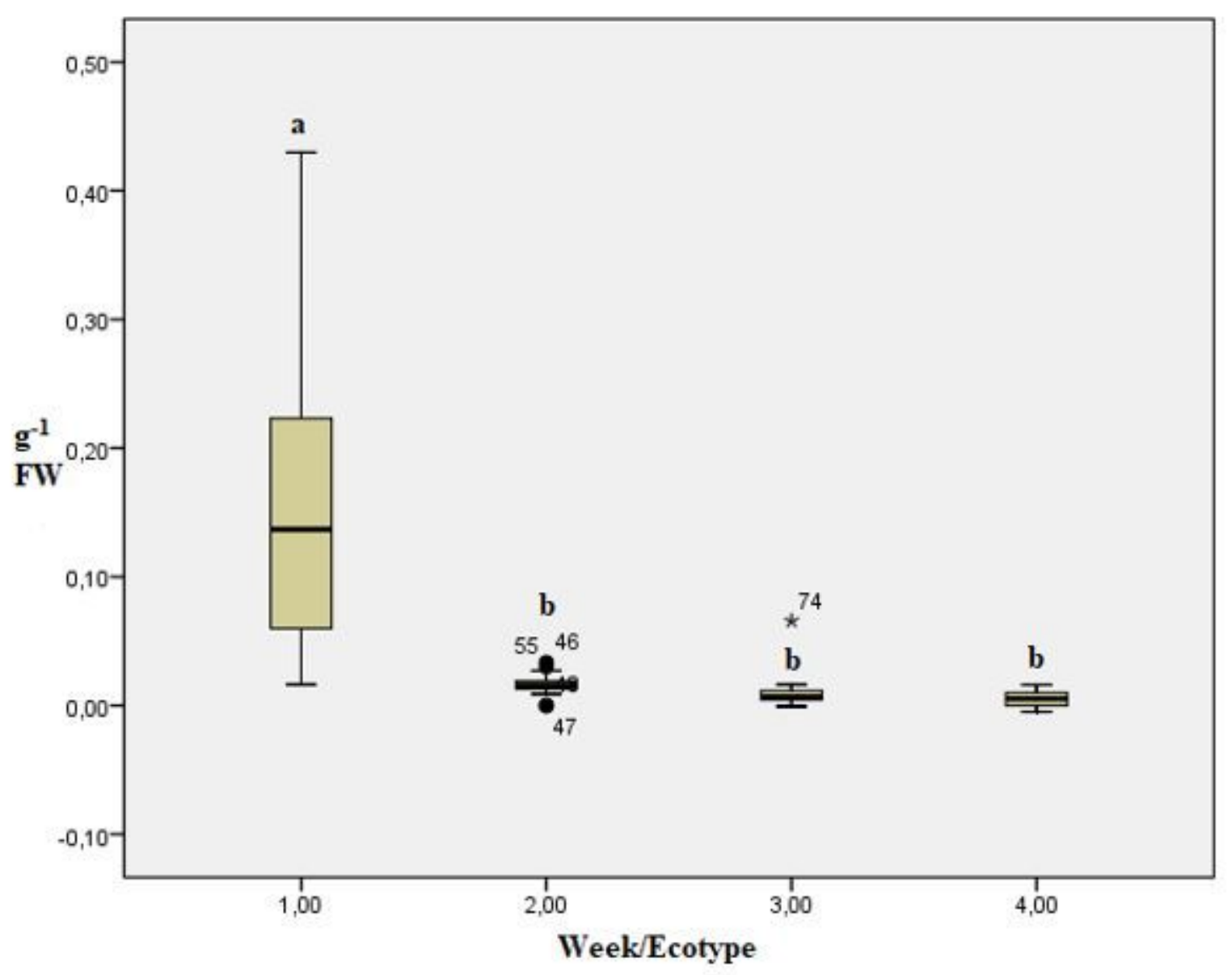

Figure 4

Changes in H2O2 acitivity alfalfa genotypes: 1: First week Muş, 2: First week Erzurum, 3: Second week Muş, 4: Second week Erzurum 1: First week Muş, 2: First Erzurum, 3: Second week Muş, 4: Second week Erzurum ( $p \otimes 0.005)$ 


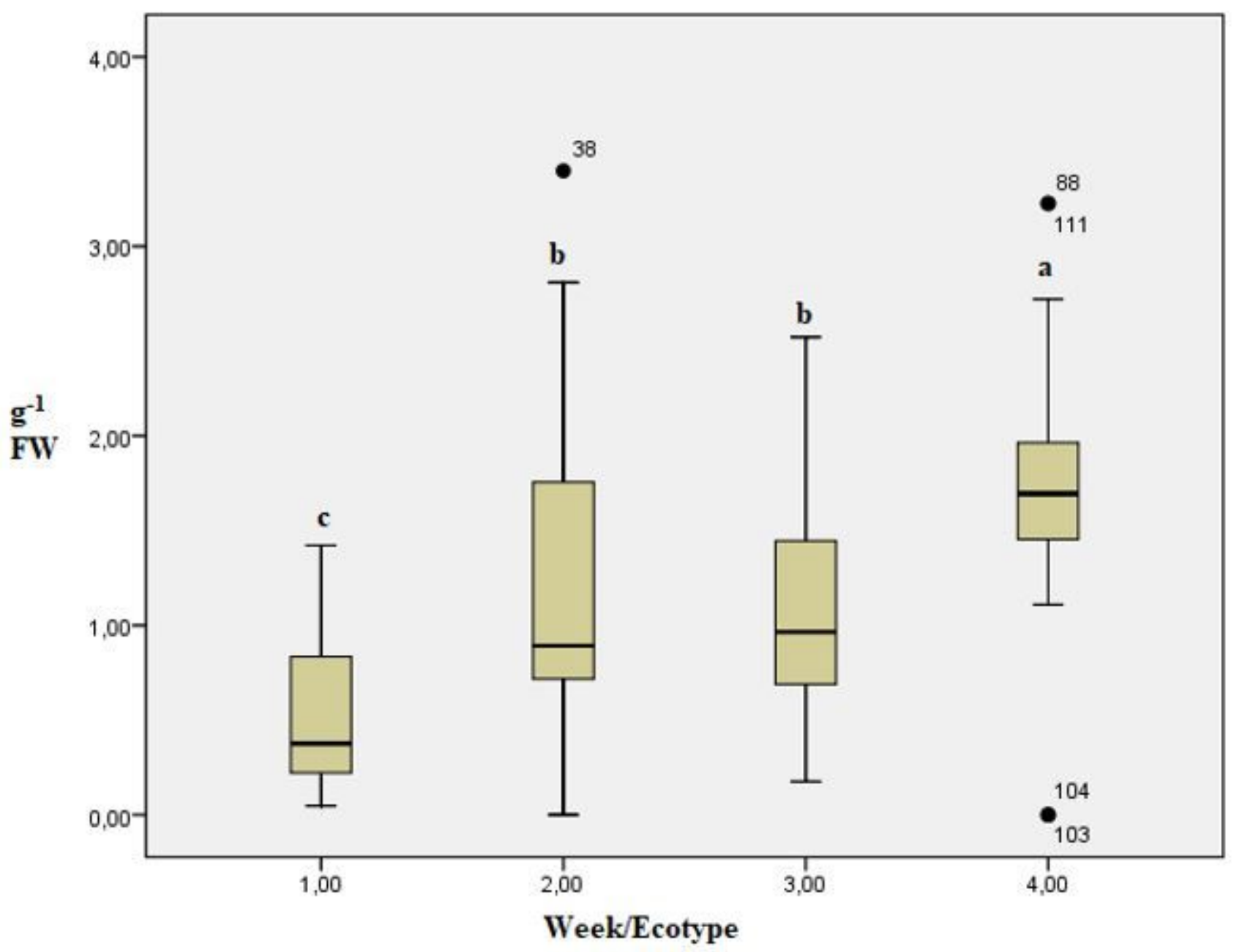

Figure 5

Changes in POD acitivity alfalfa genotypes: 1: First week Muş, 2: First week Erzurum, 3: Second week Muş, 4: Second week Erzurum 1: First week Muş, 2: First Erzurum, 3: Second week Muş, 4: Second week Erzurum ( $\mathrm{p} \otimes 0.005)$ 


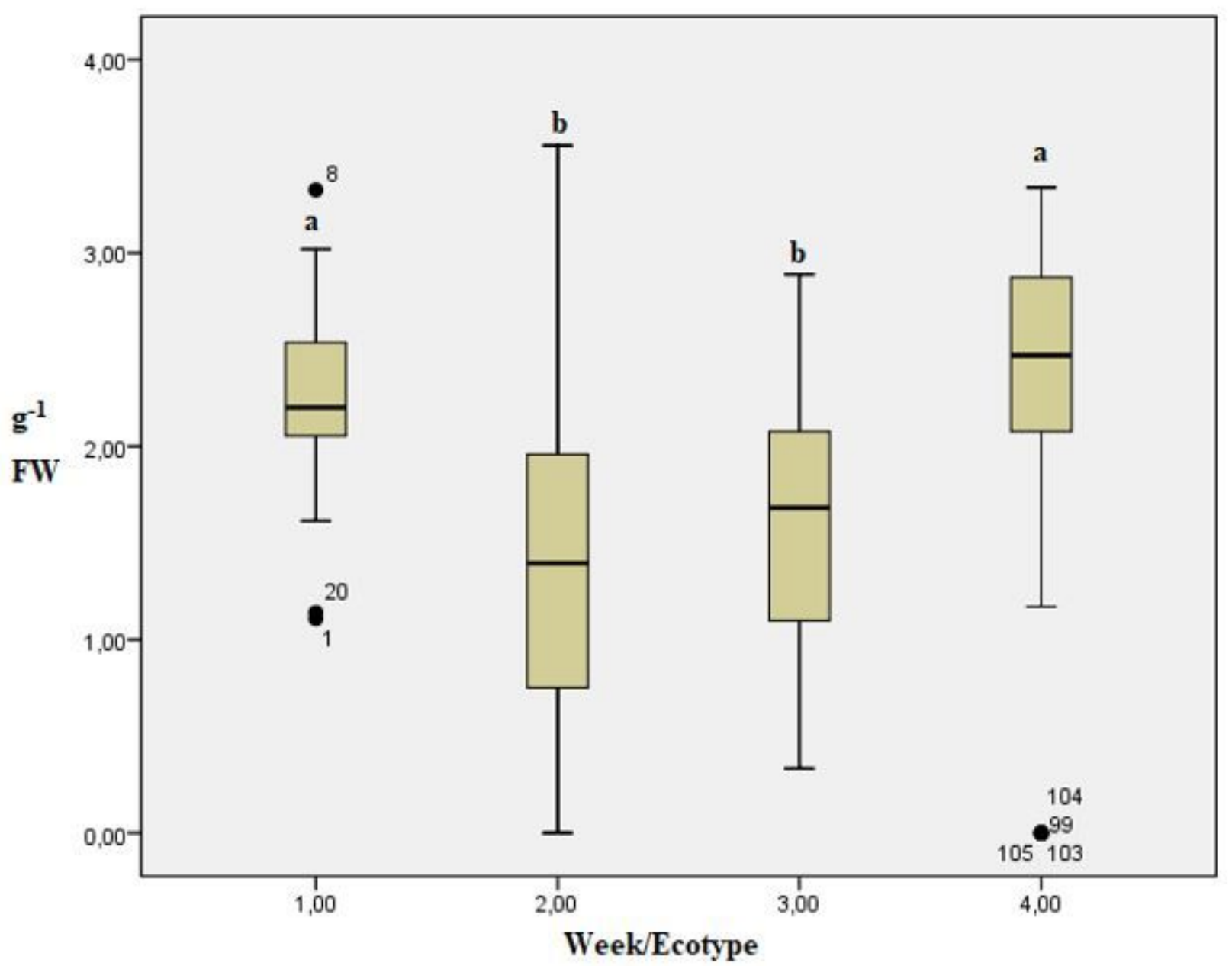

Figure 6

Changes in protein acitivity alfalfa genotypes: 1: First week Muş, 2: First week Erzurum, 3: Second week Muş, 4: Second week Erzurum 1: First week Muş, 2: First Erzurum, 3: Second week Muş, 4: Second week Erzurum ( $\mathrm{p} \otimes 0.005)$ 


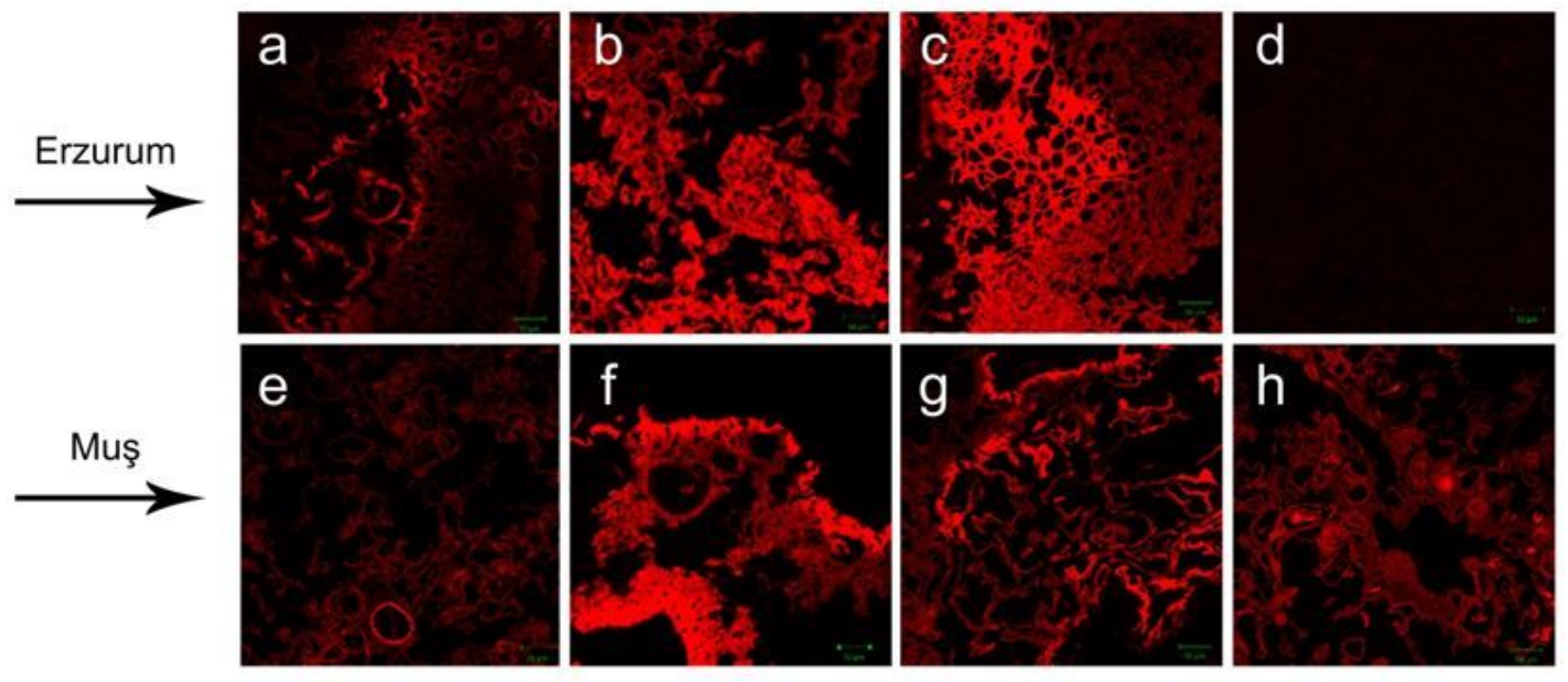

\section{Figure 7}

a Erzurum control, b Erzurum $50 \mathrm{mM} \mathrm{NaCl}$, c Erzurum 0.8 ppm CuO (+), d Erzurum 0.8 ppm CaO 50 mM $\mathrm{NaCl}(-)$, e Muş control, f Muş 50 mM NaCl, g Muş 0.8 ppm ZnO (+), h 0.8 ppm CaO 50 mM NaCl

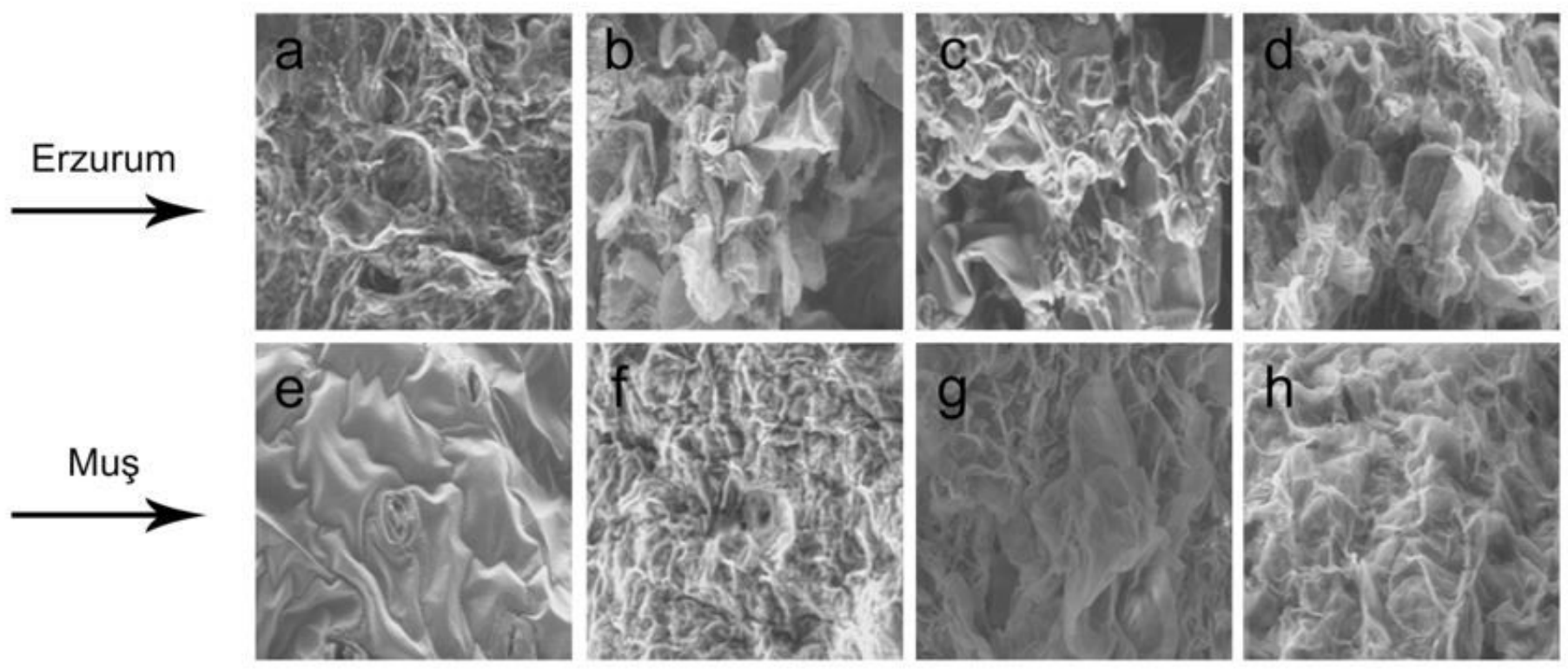

Figure 8 
a Erzurum control, b Erzurum $50 \mathrm{mM} \mathrm{NaCl}$, c Erzurum 0.8 ppm CuO (+), d Erzurum 0.8 ppm CaO 50 mM $\mathrm{NaCl}(-)$, e Muş control, f Muş 50 mM NaCl, g Muş 0.8 ppm ZnO (+), h Muş 0.8 ppm CaO 50 mM NaCl

\section{Supplementary Files}

This is a list of supplementary files associated with this preprint. Click to download.

- Table1.jpg

- Table2.jpg 